\title{
Athanassios PITSOULIS, Hildesheim \\ Greece, Turkey, the Eastern Question and the Treaty of Lausanne 1923
}

Population transfers have throughout history served governments as an instrument to achieve national or regime security objectives. Population exchanges are a special case of such transfers. Here, states enter an intergovernmental agreement in which the contracting parties decide on a reciprocal voluntary or involuntary transfer of populations. The perhaps most crucial precedent for such a measure is the Greco-Turkish population exchange agreed at Lausanne in 1923. The present paper recalls the events that led to the agreement, which essentially legitimised ex post one of the greatest humanitarian catastrophes of its time in order to solve the thorny Greco-Turkish minority problem once and for all. Relying mainly on the conference protocols I argue that the compulsory nature of the exchange was imposed under duress, but against the wishes of the affected minorities, and in clear violation of the nascent international system of human rights.

Keywords: Eastern Question - Greco-Turkish War - Greece - Lausanne Conference Ottoman Empire - Population Exchanges - Turkey

\section{Introduction}

"When the formula of political nationality is applied to mixed populations where nationality is hard to disentangle from profession or class, an irreducible residuum of minorities is bound to be left on the wrong side of the definitive frontier lines, and this residuum is a fruitful cause of estrangement. Each nation fears that its own hostages in the other's territory may be illtreated, and that the other's hostages in the own territory may undermine its sovereignty, and such expectations have a fatal tendency to realise themselves." ${ }^{\prime}$

Population transfers have throughout history served governments as an instrument to achieve national or regime security objectives like power consolidation, the creation of ethnic or religious homogeneity, control over security-relevant

\footnotetext{
${ }^{1}$ ToYnBEe, The Western Question 322f.
}

areas, etc. Population exchanges are a special case of such transfers. Here, states carry out a transaction that essentially consists of an intergovernmental agreement in which the contracting parties decide on a reciprocal voluntary or involuntary transfer of populations. Agreements of this kind "correct" the allocation of citizens to nation states according to the wishes of the contracting parties and fall into a special category of state-imposed forced migration.

The perhaps most crucial precedent for such a measure is the Greco-Turkish population exchange agreed at Lausanne in 1923. It put an end to more than two thousand years of Greek history in Anatolia and thus represents an important turning point in European history. The GrecoTurkish population exchange agreement also represents a legal and political watershed which has had a profoundly negative effect on the international community's tolerance of forced migration. One can very well make the case that the legal precedent afforded by the Greco- 
Turkish population exchange exposed minorities in nation states to the threat of governments conspiring with each other to effectuate their eviction - and the international community to sanction these evictions ex post.

Although almost a hundred years have passed since the Greco-Turkish population exchange, research has only rather recently started to critically assess what the "exchange" really meant for those evicted, for their communities, their native countries, and their destination countries. Early works on the subject, in line with the "official" national histories of Greece and Turkey, often swept the negative aspects and wider context of the population exchange under the carpet. ${ }^{2}$ In the Greek reading of national history the story of the population exchange is about the heroic efforts of the Greek state in transforming a refugee catastrophe of unprecedented dimensions into an economic success. In the official Turkish reading the same population exchange is treated as a mere footnote in the epic story of the emergence of the modern Turkish state from the ruins of the Ottoman Empire; the nonTurkish past of large parts of Anatolia is deliberately left out of the picture. ${ }^{3}$ Clearly, both sides preferred to leave important aspects of the population exchange out of their national-subjective historical narratives.

This selective perception led to a "positive reinterpretation" of the exchange. In the works of early authors, the speeches of politicians, and in the national historiographies the Lausanne agreement, which in essence legitimised ex post large-scale expulsions of Christians from Turkey by approving the expulsion of Muslims from Greece, became a "successful" population exchange and thus a model for "statesmanlike farsightedness". In recent years, however, some

\footnotetext{
${ }^{2}$ Cf. eg. MacARtney, National States; LADAS, Exchange of Minorities.

${ }^{3}$ Cf. eg. YILDIRIM, Diplomacy and Displacement 25;

MiLlAS, Exchange of Populations 221-233.
}

authors have called for a revision of the conventional view and pointed out not only the coercive nature of the population exchange, the human suffering associated with it, but also the negative consequences for the security of minorities worldwide. ${ }^{4}$

The Lausanne agreement essentially transformed one of the greatest humanitarian catastrophes of its time, viz., the expulsion of the Greeks - or, more precisely, Greek Orthodox Christians regardless of their ethnicity - from Anatolia and Asia Minor, into a population exchange sanctioned by international law and thus into an apparently rational solution of the thorny Greco-Turkish minority problem. I argue in the present paper that this "solution" was imposed ex post against the wishes of the affected minorities and in clear violation of the nascent international system of human rights. That this was certainly clear to the contracting parties explains why all involved actors emphatically but farcically rejected the responsibility for proposing the population exchange during the very negotiations at Lausanne. As I will show in this paper, a close reading of the protocols strongly suggests that the exchange was proposed by the Turkish side. The other parties grudgingly agreed to the Turkish proposal in order to "solve" the tiresome minority and refugee problem quickly and decisively. Older precedents were used as a blueprint and unwilling actors, particularly the Greek representatives, were put under intense pressure to accept a proposal nobody wanted to be associated with.

The present paper is structured as follows: In the next section I will outline the immediate historical context, particularly the Greco-Turkish War of 1919-1923, and the legal precedents to the Lausanne agreement. In Section 3 I throw some light on the negotiations at the Lausanne confer-

\footnotetext{
${ }^{4}$ Cf. eg. HiRschON, Crossing the Aegean.
} 
ence, relying mainly on the conference protocols. In Section 4 I sum up and conclude.

\section{Historical context}

"The collapse of the Ottoman Empire at the onset of the twentieth century provided the backdrop for a hundred years of genocide and ethnic cleansing in southeastern Europe and Anatolia. [...] As a result of the Balkan Wars, massive population transfers and ethnic separatism first became part of modern European conflict and made their way into the vocabulary of peacemaking." ${ }^{5}$

\subsection{From the Balkans to Asia Minor 1912-1919: The precedents of Constantinople and Neuilly}

The geopolitical questions that emerged between the $18^{\text {th }}$ and the early $20^{\text {th }}$ centuries by the disintegration of the Ottoman Empire formed the core of the so-called "Eastern Question". Initially only the Great Powers of Europe and later the nascent Arab and Balkan states competed for control of the territories the Ottoman Empire was expected to lose. The Treaty of Karlowitz in 1699 set the stage for the future dissolution of the Ottoman Empire. Especially the Russian Empire was able to quickly increase the territory under its control at the expense of the Ottomans. The geopolitical consequences for the Central and Western European powers in combination with the emergence of nationalist movements after the French revolution then transformed the Eastern Question into a serious rivalry between the major European powers.

In this rivalry, alliances shifted quickly. In 1853 conflicts of interest between Britain, France, and Russia led to the Crimean War. After the Treaty of Paris (1856), the Sublime Porte promised to

${ }^{5}$ NAIMARK, Fires of Hatred 17. improve the lot of its Christian subjects in return for protection by the Great Powers. Yet events in the Balkans led to further rivalry and destabilisation. Frustrated by the duplicity of the Great Powers, the Ottomans ended up on Germany's side even before the Great War. After the end of the war, the violent dismantling of the weakened Ottoman Empire reached its climax. This was accompanied by large expulsions and voluntary emigration of Muslims from the lost Ottoman territories. ${ }^{6}$ After the Ottomans were crucially weakened by their defeats in the Libyan War against Italy (1911) and the loss of the Dodecanese (1912), the loose Christian Balkan alliance (Bulgaria, Greece, Montenegro and Serbia) defeated the Ottoman Empire in the First Balkan War (1912/13). Conflicting claims regarding the spoils of that war then triggered the Second Balkan War of 1913, in which Bulgaria turned against its former allies Greece and Serbia. In the course of this war, Bulgaria lost the Dobruja region to Romania, East Thrace to the Ottomans and Macedonia to Greece and Serbia.

As part of the negotiations over the transfer of East Thrace to the Ottomans, Bulgaria, and the Sublime Porte concluded the Constantinople Agreement on 29 September 1913. In this treaty "for the first time in [modern] history two states agreed on a population exchange based on the ethnicity of the individuals affected. The aim was to purify the border zone of nationals of the other state." 7 The exchange entailed the mutual resettlement of those Bulgarians and Muslims, and the regulated exchange of their property, who lived within a $15 \mathrm{~km}$ wide zone along the border between the two states. As a result, 47,000 Bulgarians and 49,000 Ottoman Muslims were exchanged. ${ }^{8}$ The population exchange was, in fact, not a pre-emptive measure to solve the

\footnotetext{
${ }^{6} \mathrm{Cf}$. BoEKH, Balkankriege.

${ }^{7}$ KORB, Homogenizing Europe 377; cf. SCHECHTMAN, Populations Transfers 12.

${ }^{8}$ Cf. ICDUYGU, Changing Waves 88.
} 
bilateral minority problem but an ex-post legitimisation of expulsions that had already taken place. ${ }^{9}$ Importantly, although the treaty was "just a legal footnote to the mass expulsions that affected hundreds of thousands of Greeks, Bulgarians, Serbs, Albanians and Turks during the bloody wars of 1912/13, [...] it was a treaty that set a trend." 10

The First World War led to further territorial changes in the Balkans. The British government under David Lloyd George offered Greece the annexation of the Greek-populated areas of Asia Minor and Cyprus after the Ottoman Empire entered the war on the German side. ${ }^{11}$ In order to persuade Bulgaria to join the allied war effort, the Greek Prime Minister Venizelos - probably inspired by the Treaty of Constantinople - proposed in a memorandum to the Greek King Constantine a comprehensive Bulgarian-Greek population exchange. ${ }^{12}$

In early 1914 the Ottoman authorities began to deport the Greek population of Asia Minor and the Black Sea coast to Central Anatolia and to settle Muslim refugees from Macedonia in the violently depopulated regions. ${ }^{13}$ This measure was officially justified with security concerns. The Sublime Porte perhaps also wanted to put pressure on the Greek government to conclude an agreement on a comprehensive population exchange, as Greek economic activity was systematically boycotted at the same time. ${ }^{14}$ Similar to what would happen nine years later, the Ot-

\footnotetext{
${ }^{9} \mathrm{Cf}$. SMITH, Sovereignty 170.

${ }^{10}$ KORB, Homogenizing Europe 377. Together, the two Balkan Wars led to the displacement of some 700,000 people. Vgl. SMITH, Sovereignty 170, as well as PENTZOPOULOS, Balkan Exchange 55.

${ }^{11}$ Cf. Llewellyn-Smith, Venizelos' Diplomacy 148.

${ }^{12}$ Cf. ID., Ionian Vision 47.

${ }^{13} \mathrm{Cf}$. BOEKH, Balkankriege 270. According to one estimate approximately 500,000 people were deported. Vgl. Pentzopoulos, Balkan Exchange 57.

${ }^{14} \mathrm{Vgl}$. PAllis, Exchange of Populations 2; YILDIRIM, Diplomacy and Displacement 6.
}

toman envoy in Athens, Galip Kemali Söylemezoglu, presented the Greek Government with a "private proposal" in this direction. ${ }^{15}$ In June 1914, a mixed commission was set up to visit the regions concerned. ${ }^{16}$ On 5 July 1914, the Sublime Porte accepted Venizelos' conditions in a diplomatic note. The agreement concerned the voluntary transfer of the Greek-speaking population from the Turkish part of Thrace and the Ottoman province of Aydin in Asia Minor on the one hand, and the Muslim population in the Greek part of Macedonia and Epirus on the other (approximately one million people in total). In contrast to the Treaty of Constantinople between the Ottomans and Bulgaria, the population exchange was devised as a pre-emptive measure, and was meant to diffuse the tense relations between Greece and the Ottoman Empire. The agreement thus represented a new approach towards the question of how to deal with national minorities. The Ottomans' entry into the First World War, however, interrupted the work of the Greco-Ottoman Commission responsible for drafting the agreement. It was thus never ratified.

Seen in retrospect, the 1913 and 1914 agreements "may be deemed the forerunners of the Convention of Neuilly of 1919 and the Convention of Lausanne of 1923, for they prepared the ground for the idea of the exchange of populations as a radical but possible means of solving the painful, age-old problem of ethnic minorities in the Balkans."17 The agreements inspired, for instance, the Swiss anthropologist Georges Montandon to present a vision of the European continent ethnically cleansed through "massive resettlement" at a conference in 1915. ${ }^{18}$

In October of that year, Bulgaria decided to enter the war on the German side, thus re-igniting

\footnotetext{
${ }^{15}$ Cf. Pentzopoulos, Balkan Exchange 56.

${ }^{16}$ Cf. YILDIRIM, Diplomacy and Displacement 6.

17 SCHECHTMAN, Population Transfers 13.

${ }^{18}$ MONTANDON, Frontières nationales 8f.
} 
the Balkan conflict. In Greece a constitutional crisis led to intervention by the great powers, and to what would become known as the "National Schism". A coup by anti-royalist officers in Thessaloniki in August 1916 split Greek society in half: The royalists preferred neutrality while the "Venizelists" wanted to enter the war on the side of the Entente. Venizelos took over the government in June 1917 and led the country to war against Bulgaria.

After the collapse of the Ottoman Empire, Venizelos asserted the Greek claims: Asia Minor, home to Greeks since antiquity, with the great port city of Smyrna was to join Greece. The Mudros Armistice Agreement of 30 October 1918 - tellingly signed on board the British battleship HMS Agamemnon - provided the legal basis, as the Sublime Porte granted the Allies the right to occupy any Ottoman territory in the event of unrest. Allied troops entered Constantinople already in November 1918. The Paris Peace Conference drew up a series of peace treaties between the victorious powers and the losers of the First World War. The Greek delegation benefited from Venizelos' radiant reputation, but came into conflict with the American delegation under President Woodrow Wilson over their demands regarding the Greek Orthodox minority in Asia Minor. In contrast to Wilson, the British Prime Minister Lloyd George took a positive view of the Greek demands despite serious concerns in his cabinet and army leadership. The Greek occupation of Asia Minor thus had a contractual basis and powerful political advocates. Winston Churchill later summarised the situation thus: "At last peace with Turkey: and to ratify it, war with Turkey! However, so far as the Great Alliances were concerned the war was to be fought by proxy. Wars fought this way by great nations are very dangerous for the proxy." 19

\footnotetext{
${ }^{19}$ ChURChILL, World Crisis 377.
}

After reports of Turkish attacks on Christians, the Greek government received in May 1919 a mandate from France, Great Britain, and the United States to occupy Smyrna. Venizelos expected that Greeks from other parts of Anatolia would migrate to the city and that this would result in an ethnic homogenisation..$^{20}$ The Greek occupation was one of four Allied measures to secure zones of influence in Anatolia, and in May 1919 the first Greek troops were landed.21 The city of Smyrna itself was a multicultural metropolis with hundreds of thousands of inhabitants and belonged to the cities in Asia Minor in which Greeks formed a plurality, perhaps even a majority. Yet the concessions granted to Greece were in direct conflict with those granted to Italy, as the latter had already been promised control of the Antalya and Smyrna regions by Great Britain and France in the secret agreement of St. Jean-de-Marienne in return for Italy's entry into the war on the Allies' side.

In the Treaty of Neuilly of 27 November 1919, Venizelos achieved the annexation of Western Thrace, which had been under Bulgarian occupation, to Greece. One of the treaty instruments of the agreement was the Convention on a Bulgarian-Greek Population Exchange, which provided for the reciprocal voluntary migration of Bulgarians and Greeks. A total of 22,000 Bulgarians and 46,000 Greeks emigrated.22 In the Treaty of Sèvres of 10 August 1920, Venizelos secured the annexation of Eastern Thrace, as well as control over Smyrna and the Ottoman province of Aydin in Asia Minor, which after five years could decide by plebiscite whether or not to become part of the Hellenic Kingdom. In the same treaty France and Italy, too, defined their spheres of influence in the defeated Ottoman Empire. Italy and Greece reached an agreement on 10 August 1920 in which Italy renounced the

\footnotetext{
${ }^{20}$ BLOXHAM, Great Game 156.

${ }^{21}$ Nicholson, Curzon 92.

22 WOLFF, Population transfers 12.
} 
Dodecanese and committed to ceding these islands to Greece after a period of 15 years.

\subsection{The Asia Minor catastrophe and the fate of the Greek Christians}

The disembarkation of the Greek army in Asia Minor took place in an extremely heated climate. Reports of attacks on the Greek Orthodox civilian population since 1914 did not escape the army. The fact that in view of these events the great powers had done nothing to protect the Ottoman Greek-Orthodox Christians reinforced the impression among many Greeks that their own nation could not rely on its allies for the protection of its kin in Anatolia. On the other hand, the Ottoman Empire had for years been taking in large waves of refugees from the Balkans, and most Ottoman Muslims regarded Anatolia as their motherland. Most of them were incensed about the fact that many of their kin were now under occupation by their former Christian subjects.

An isolated attack on Greek soldiers during the entry into Smyrna led to riots that claimed hundreds of victims. Soon a veritable vicious circle of violence began to develop: Greek attacks on Muslims triggered attacks by armed Turkish nationalist irregulars on the Greek civilian population and vice versa. The Greek army was unable to prevent the participation of its soldiers in the fighting. In order to restore law and order, to protect Greek villages, and to persecute the Turkish irregulars, the Greek army leadership decided to expand the occupied territory further and further into Asia Minor. This was probably a strategic necessity, given the military geography of Anatolia. According to Arnold Toynbee, who had surveyed the region as special correspondent of the Manchester Guardian in 1921, every attacker from the West was forced to extend his front to the east but in so doing made his flanks vulnerable to advances from the Cen- tral Anatolian highlands. ${ }^{23}$ As the war went on, both sides made increasingly ruthless use of expulsions and massacres. General Mustafa Kemal meanwhile organised the Turkish nationalist resistance, which was fanned by the advance of the hated Greeks. At the same time there were sporadic attempts by the Allies to disarm Ottoman army units in accordance with the orders of the winners of the First World War. At the same time, French units fought against Turkish nationalist forces in Cilicia.

Meanwhile the negotiations in Paris continued. The Treaty of Sèvres was signed on 10 August 1920. Within a few weeks, the Greek army was able to consolidate its positions in Eastern Thrace and Asia Minor. The treaty was presented to the Greek parliament in September; now the domestic dimension of Greece's expansionary policy became clear: Venizelos had new elections called immediately, and the Greek population of Eastern Thrace was quickly made eligible to vote. Venizelos' liberal party, however, surprisingly lost the general election in November. Thus the "National Schism" was imported into the army. At all levels of the officer corps, pro-British Venizelists were replaced by pro-German royalists. Morale and fighting power of the Greek expeditionary forces were, of course, seriously and negatively affected.

The October Revolution in Russia and the growing resistance of the Turkish nationalists to the Treaty of Sèvres led to a fundamental foreign policy reorientation within the Entente. The collapse of the Allies' coalition due to incompatible interests in the Ottoman Empire led Lloyd George to completely rely on the Greek government to enforce compliance with the Sèvres Treaty through military action and, if necessary, against the resistance of the other Allies. The Greek army and navy was the only remaining instrument to secure strategic British interests

${ }^{23}$ TOYNBEE, Western Question 214f. 
regarding the land connection to India as well as access to the Suez Canal. Yet the geopolitical situation changed fundamentally in April 1921, when Britain declared itself neutral after France and Italy broke with Greece. The Bolsheviks began supplying Ankara, while Britain stopped supplying the Greek army. Suddenly all circumstances conspired and turned the tables on the Greeks.

After the Greek army failed in its last-ditch effort to bring the war against the Turkish nationalists to a successful conclusion and went from the offensive into grinding halt while the far superior Turkish army continued to reinforce its positions, the Turkish government proposed a comprehensive Greek-Turkish population exchange to the British Foreign Minister Lord Curzon in May 1922. ${ }^{24}$ Yet an agreement could not be reached because the Turkish nationalist government would not consider a ceasefire without the evacuation of the Greek troops; the Greek government would not consider to evacuate Smyrna and leave the city defenceless. In late August 1922, the Greek odds completely evaporated and the Hellenic army's retreat turned into a hopeless flight; the battle-weary and scattered troops tried to slow down the rapid Turkish advance as much as possible by implementing a strategy of scorched earth. Under constant pressure, the Greek army fled towards the western coast of Asia Minor; what remained of the once victorious army was shipped out by the Greek navy and send directly to Eastern Thrace. The civilians, inhabitants of the coastal cities and villages as well as refugees from the interior, were left behind defenceless and at the mercy of the victorious Turkish nationalist army. Said army entered the city of Smyrna on 9 September 1922. Foreign correspondents reported terrible incidents that claimed a total of about 100,000 lives. Smyrna was almost completely destroyed

\footnotetext{
${ }^{24}$ YILIDIRM, Diplomacy and Displacement 41.
}

by fire. To this day, Greeks and Turks blame each other for the destruction of the city. ${ }^{25}$

By early October 1922, nearly 300,000 survivors had been evacuated. Yet all Armenian and Greek men between the ages of 15 and 50 (in total at least 30,000 people) were deported into Anatolia by the Turkish army. Most never returned. Now "Greeks were not only expelled from western Anatolia and Smyrna but were moved out of towns and villages in the interior, out of Cilicia in the south, and out of the heavily Greek Pontic region along the Black Sea coast [...] As in Smyrna, the Turks did little to relieve the suffering of the refugees precisely because of the policies to evict them as soon as possible."26

A short time later, Turkish troops also occupied the British-controlled Dardanelles. The Mudanya Armistice Agreement of 11 October 1922 established Turkish sovereignty over East Thrace; the region was immediately evacuated by the Greek army. A few days earlier, the High Commissioner of the League of Nations, Philip NoelBaker, had travelled to Constantinople in the company of Dr. Fridtjof Nansen, the League's Commissioner for Refugees. A quick solution to the refugee problem had to be found, and the Smyrna disaster was widely reported in the international press. After some fruitless discussions, the Turkish Director General for Refugee Affairs and head of the Turkish Red Crescent, ${ }^{27}$ a certain Hamid Bey, announced to Nansen that for the Turkish regime only a total and compulsory population exchange would be acceptable. ${ }^{28}$ Nansen presented the Turkish representative with a draft treaty based on the Bulgarian-Greek population exchange. Perhaps because this agreement included voluntary emigration the Turkish government rejected it immediately.

\footnotetext{
${ }^{25}$ NAIMARK, Fires of Hatred 51f.; cf. KASSABA, Izmir 1922; MILTON, Paradise 307.

${ }^{26}$ NAIMARK, Fires of Hatred 53.

${ }^{27}$ FRANK, Minorities 51.

${ }^{28}$ YILDIRIM, Diplomacy and Displacement 43.
} 
Nansen then wrote in a letter to Venizelos: “Everyone appears to agree that it is hopeless to expect either the Turks will agree to receive [the evicted Greeks] again in Asia Minor, or that the refugees themselves would agree to go even if they were received. They must therefore be settled elsewhere and I presume that it will be the purpose of the Greek government either as a result of the Treaty for the exchange of populations with the Turkish government or without such a Treaty to settle them in the vacant Lands of Macedonia or Western Thrace." ${ }^{29}$ It is against this background that the negotiations at Lausanne must be seen.

\section{The Negotiations at Lausanne}

In November 1922, Great Britain, France, Italy, Japan, Greece, Romania, the Serbo-CroatianSlovenian Kingdom, and Turkey began their peace negotiations at Lausanne. The situation resembled a barter trade in which entire population groups and territories were set off against each other. The main actors on the GreekTurkish issues were the British Foreign Minister, Lord Curzon, the now former Greek Prime Minister Venizelos and the Turkish General Mustafa Ismet, who had previously fought successfully against the Greek troops in Asia Minor but had no diplomatic experience whatsoever.

The conference marked the end of an era of geopolitical upheaval, but not of the suffering of the affected populations. The delegations of the participating states were bombarded with protest letters and petitions from minority representatives, refugees and others. The atmosphere must have been quite tense, since the alternative to a negotiated solution was the resumption of hostilities. The conference dragged on for months and broke up in February 1923. Talks could only be resumed after American media-

\footnotetext{
${ }^{29}$ Ibid. 48.
}

tion. The negotiations on the Greco-Turkish population exchange took place in the very first phase of the conference.

According to the American statistics cited by the British delegation, there were an estimated 1.6 million Greeks in Asia Minor in 1914. By the time the negotiations began on a Greco-Turkish population exchange, some 1 to 1.1 million had either been murdered or displaced, fled or lost their lives in the turmoil of war. ${ }^{30}$ The remaining Greek minority in Turkey that would be affected by the forced resettlement amounted to between 500,000 and 600,000 people. In addition, there were about 320,000 Greek refugees from Eastern Thrace and about 50,000 surviving Armenian refugees. In addition, around 350,000 Greeks lived in Constantinople, who the Turkish government wanted to get rid of, although - or perhaps because - they were responsible for most of the economic output of the metropolis. The number of Muslims in Greece was estimated at 450,000 to 480,000 people. With a total population of about 4.5 million, the Greek state faced an influx of 1.2 to 1.5 million refugees. This situation has to be seen against the background of an absolutely catastrophic economic situation caused by 12 years of permanent warfare. ${ }^{31}$ Domestic means to provide for the refugees were simply not available.

Both the Greek and Turkish governments as well as the Great Powers were also confronted with the problem that a compulsory population exchange was highly unpopular. Many Greek refugees expelled from Turkey still hoped to return home, while Muslims in Greece feared the prospect of deportation to Turkey. The international press was not in favour of forced population exchange either. ${ }^{32}$

\footnotetext{
${ }^{30}$ Cf. Meindersma, Population Exchanges 341.

${ }^{31}$ Cf. VALKAlOPOUlOS, Griechische Geschichte 202.

${ }^{32}$ Cf. Meindersma, Population Exchanges 341.
} 
Curzon dominated the negotiations by acting as the agenda setter: ${ }^{33}$ The order of the negotiation items was deliberately arranged in such a way that the issues in which the Turkish delegation had a weak position were dealt with first and in commissions under his chairmanship. The aim was to demonstrate Allied solidarity and to put pressure on Ismet, who always had to coordinate his decisions with Ankara. In order to gain time for this, Ismet constantly tried to delay the negotiations by reserving the right to make further statements. The British delegation, on the other hand, was well informed about the instructions given to Ismet by Ankara through its espionage activities. ${ }^{34}$

The first talks on the population exchange were held at the eighth meeting of the Territorial and Military Commission chaired by Lord Curzon on 1 December 1922. Early in the talks, Nansen, in his capacity as representative of the League of Nations for Refugee Affairs in Constantinople, was asked by Curzon to make a statement. In this Nansen made clear that the initiative for some form of population exchange came from the Great Powers: "It was while I was engaged on this task that I was invited by the representatives of the four Great Powers in Constantinople to endeavour to initiate negotiations between the Turkish and Greek Governments with a view to the conclusion of a treaty for the exchange of minority populations. In view of the fact that the Governments of the four Great Powers all believed such an exchange to be desirable, and as I shared their view that such an exchange, if it were made, should be made at once and without waiting for the conclusion of the final Treaty of Peace, I immediately entered into negotiations with the two Governments with a view to arranging an immediate agreement. [...] I know that the governments of the

\footnotetext{
${ }^{33} \mathrm{Vgl}$. hierzu und zum Folgenden Nicholson, The Last Phase 292.

${ }^{34}$ Vgl. KeITH, Lord Curzon.
}

Great Powers are in favour of this proposal because they believe that to unmix the populations of the Near East will tend to secure the true pacification of the Near East and because they believe an exchange of populations is the quickest and most efficacious way of dealing with the grave movements of populations which has already occurred." 35

Nansen advocated a speedy conclusion because the economic consequences of the huge population displacements were severe. Furthermore, from a "political and psychological" point of view, it was easier to carry out the exchange while people were still on the move. It was also important to clarify whether the exchange should be voluntary or compulsory. This question was absolutely crucial and still open: A voluntary exchange would mean a right of return for the displaced Greeks and give the Greek Muslims concerned by the treaty the freedom of choice to remain in the country. A compulsory exchange would deprive Greek displaced persons of the right to return; the Greek Muslims concerned would be deported against their will if necessary. Ismet and Venizelos expressed surprise that the issue was not on the agenda, but Curzon pointed out that they had never committed themselves to a particular solution. It was then quickly agreed to discuss the issue in a sub-committee consisting of a Greek and a Turkish representative and a chairman appointed by the president. This sub-commission was chaired by Giulio Cesare Montagna, the Italian Ambassador to Athens. Curzon urged the Greek and Turkish representatives to start talks on population exchanges immediately. If they could not be finished on the very same afternoon, the Greeks and Turks should continue negotiations as soon as possible, since human lives depended on a quick solution. ${ }^{36}$ In the end, this sub-commission

\footnotetext{
${ }^{35}$ Lausanne Conference 114.

${ }^{36}$ Lausanne Conference 118.
} 
met 24 times during the negotiations in Lausanne; no other sub-commission met more frequently. Issues related to population exchange were also discussed in the sub-commission on the protection of minorities, which met 17 times. The first statements of the Greek and Turkish delegates showed where the friction points would lie in the negotiations: Ismet was basically in favour of a population exchange, but in his view this was linked to the general question of minorities in Turkey and should only be discussed after more urgent questions were solved. ${ }^{37}$ It also was the position of the Turkish government that the Greek inhabitants of Smyrna and Constantinople should be resettled as part of an exchange agreement. ${ }^{38}$ Ismet accused Venizelos of wanting a compulsory exchange himself for political reasons; Venizelos emphatically pointed out that he did not wish the Turkish population of Greece to be forcibly deported. He had a voluntary exchange in mind. ${ }^{39}$ Curzon, for his part, made clear his own preference for a compulsory exchange: "He would like to add a word upon the principles to be adopted. M. Veniselos was prepared to consider either the voluntary or the compulsory exchange of populations. Doubtless everyone would instinctively prefer a voluntary exchange if that were possible. Exchange had been voluntary in the GreekBulgarian ease. If a sub-commission were appointed, they would no doubt consider the matter; but he thought that compulsion would very probably be found necessary for more reasons than one. If the exchange were left on a voluntary basis, months might pass before it was carried out, whereas what was wanted was firstly to get the Turkish population back into Eastern Thrace so that they might till the soil early next year; and, secondly, to provide for the accommodation in Greece of the refugees pouring in

\footnotetext{
${ }^{37}$ Lausanne Conference 117.

${ }^{38}$ Lausanne Conference 120.

${ }^{39}$ Lausanne Conference 120.
}

from other parts. Also if the exchange were compulsory, it would be easier to secure payment for the property which people were obliged to leave behind them." 40

After several meetings of the sub-commission, the topic was taken up in the discussion on minority rights at the 13th and 14th meetings of the territorial and military commissions on 12 and 13 December 1922. The Turkish delegation still insisted that all Greek inhabitants of Constantinople should leave Turkey. Curzon then increased the pressure on the Turkish delegation by referring to minority protection clauses for the Turkish minority in Western Thrace: "In Europe the greater part, if not the whole, of the Turkish population in Greek territory, with the exception of Western Thrace, will cease to be a minority population because they will return to Turkey. They are estimated at about 350,000 persons. The exception, as I have said, will be the 124,000 Turks in Western Thrace whom the Greek Government is prepared to leave alone if the Greek population of Constantinople is also left undisturbed. In that case the minority provisions will apply to the Turkish population. If no such arrangement can be arrived at, then they also will be turned out, and there will be no Turkish population in Western Thrace for whom provision will be required." 41

It was thus clear that the fate of the Muslim minority in Western Thrace was depending solely on the question whether the Greek inhabitants of Constantinople could remain in the city. The question was what rights should be granted to the minorities. Ismet made a long political statement which summarised the interpretation of the Ottoman minority situation from the point of view of the Turkish nationalists. ${ }^{42}$ The blame for uprisings and massacres was put on the foreign powers, especially Russia. The "most

\footnotetext{
${ }^{40}$ Lausanne Conference 120.

${ }^{41}$ Lausanne Conference 177.

${ }^{42}$ Lausanne Conference 190-204.
} 
radical and humane" solution from the Turkish point of view was the elimination of the possibility of foreign intervention by the resettlement of minorities. Both Curzon and Venizelos rejected this idea. Ismet expressed astonishment that the latter was doing so; he had assumed that the proposal for the population exchange had come from the Greek side. ${ }^{43} \mathrm{He}$ justified the Turkish demands with the argument that to prevent minorities from threatening the state as subversive elements of foreign powers was actually a rather noble cause. ${ }^{44}$ Ismet consequently rejected the monitoring of minority protection clauses by an international commission, since that would be tantamount to an interference in internal affairs; from a Turkish point of view, only minority rights on the basis of reciprocity were acceptable. ${ }^{45}$ A part of the Greek population of Constantinople might be exempted from the population exchange, but only on condition that the institution of the Ecumenical Patriarchate of Constantinople be abolished. ${ }^{46}$ Venizelos again pointed out that the proposal for a compulsory exchange did not come from the Greek delegation, but from Nansen; the Greek government was willing to accept a voluntary population exchange if the Greek refugees from Asia Minor were allowed to return to Turkey. ${ }^{47}$

Curzon, fearing an impasse, at this point openly threatened to break off the negotiations: "Lord Curzon [...] deeply regretted to hear the repeated charges in the speeches of the Turkish delegation against the Greek population and army, when similar and much greater charges could easily be brought against the Turks. [...] For his own part, he deeply regretted that the solution now being worked out should be the compulsory exchange of populations - a thoroughly bad

\footnotetext{
${ }^{43}$ Lausanne Conference 188.

${ }^{44}$ Lausanne Conference 207.

${ }^{45}$ Lausanne Conference 209.

${ }^{46}$ FRANK, Minorities, 68.

${ }^{47}$ Lausanne Conference 210.
}

and vicious solution, for which the world would pay a heavy penalty for a hundred years to come. He detested having anything to do with it. But to say it was a suggestion of the Greek Government was ridiculous. It was a solution enforced by the action of the Turkish Government in expelling these people from Turkish territory. Even now, as the proceedings of the sub-commission showed, the Turkish Government was still bent on getting rid of every Greek in Constantinople, or only allowing them to remain at the price of certain cruel conditions. Lord Curzon continued: 'When we go awayand we may go quicker than you think-the whole world will look at what we have been saying and doing here during the last two days. When the world hears that we have been fighting the battle of these minorities and have received nothing in return from the Turkish delegation but platitudes, the general impression will be deplorable.'"'48

Obviously, the question of the authorship of the idea of a compulsory exchange was highly controversial. Ismet said he never made an official proposal in this direction and instead talked only as a private person with Nansen about this. Since his first official interlocutor was Venizelos, who had gotten the 'private proposal' from Nansen and taken it up, the Greek side was to blame. ${ }^{49}$ Venizelos reacted by reading a prepared statement in which he made repeatedly clear that the Greek delegation had always rejected a compulsory exchange; should the Turkish delegation prefer a voluntary exchange, the Greek side was ready to agree. The Turkish representatives remained silent. At this point the deputy British negotiator Horace Rumbold made the following statement: "The Allied High Commissioners at Constantinople had dealt with the question in the following circumstanc-

\footnotetext{
${ }^{48}$ Lausanne Conference 212.

${ }^{49}$ Lausanne Conference 217.
} 
es: When the Greek population fled from Asia Minor in hundreds of thousands, the High Commissioners met to examine the problem. Dr. Nansen, who was at the time in Constantinople and had come there for the purpose of dealing with the question of refugees, was invited to attend these meetings, and the idea of an exchange of populations came from him. The High Commissioners, who realised the magnitude of the problem, were of the opinion that it must be settled by the conference and not by themselves. It was at this point that Dr. Nansen approached Hamid Bey, the representative of the Angora Government at Constantinople, and the latter replied categorically that the question of exchanging populations could only be considered on a compulsory basis." 50

After some more work by the sub-commissions, Curzon presented a draft peace treaty on 31 January 1923. In his opening speech, he underlined the Allies' willingness to compromise; he also referred to the negotiations on a population exchange that had been concluded the day before: "The question of minorities is one which it fell to the lot of my commission to examine, and I cannot pretend to be satisfied with the result. In my judgement the Turkish delegation would have been well advised to adopt a more generous attitude $[\ldots]$. The Allied Powers have further used their influence with the Greek delegation to secure that the difficult question of the exchange of populations shall be regulated upon a reasonable basis of reciprocity. [...] They have also - though it must be admitted with profound reluctance - agreed that the proposed exchange of populations shall be conducted on the basis advocated by the Turkish delegation, namely, that of compulsory expatriation; and finally, they have induced the Greek delegation to agree to the unconditional exclusion of Western Thrace from the scope of any exchange

\footnotetext{
${ }^{50}$ Lausanne Conference 227.
}

agreement, although the Turkish delegation have subjected the corresponding retention of the Greek population in Constantinople to several very onerous conditions. ${ }^{.51}$

The Greco-Turkish Convention was included as one of the 17 treaty instruments in the multilateral peace treaty of Lausanne of 24 July 1923 and thus sanctioned by the participating states and the League of Nations. The reaction to the outcome of the conference was "universally hostile." ${ }^{52}$ The Time Magazine commented as follows: „In effect, the Lausanne Settlement turned Europe bag and baggage out of Turkey instead of turning Turkey bag and baggage out of Europe. It signified the complete shipwreck of Lloyd George's five years' nursing of Greek ambitions. Flouting the conservative policy of seven decades, it exposed Turkey to intrigue and direct military pressure from Britain's perennial foe, Russia. It excluded France, Italy and Great Britain from exploitation of the spoils of war. It practically abandoned all pretence on the part of the Great Powers to protect the Christians in Turkey, cardinal point of Gladstone's eastern policy. The terms of the Straits Convention reduced British opportunities to checkmate Russia or bring naval pressure to bear on Turkish ambitions, cardinal point of British navalpolitical strategy. ${ }^{253}$

Thus the "unmixing of populations" culminated in the legitimisation of the Turkish expulsion of Greek Orthodox Christians and the legalised deportation of most Greek Muslims to Turkey against their will. The Greek-Turkish population exchange was ultimately enforced by coercive measures on both sides; the former enemies, ironically, now cooperated in its implementation.

\footnotetext{
${ }^{51}$ Lausanne Conference 433f.

52 FRANK, Minorities 71.

53 Time Magazine, 14 April 1924, 2.
} 


\section{Conclusion}

It is important to understand that the GrecoTurkish population exchange agreed at Lausanne was not a voluntary, quasi-economic transaction between states. The Greek government was forced to accept the expulsion of the Greek Orthodox Christians from Turkey and then make the best of it. The forced resettlement of the Greek Muslims of Macedonia was a direct consequence of Turkey's unyielding attitude towards the return of Greek refugees.

Seen from a human rights perspective, Lausanne was a step backwards from existing standards. ${ }^{54}$ Earlier agreements on the exchange of populations (Constantinople, Neuilly) were not of a compulsory nature. The resettled minorities also were not guaranteed the same level of protection the Lausanne treaty afforded to the minority groups that were excluded from compulsory resettlement. The minorities left in Greece and Turkey nevertheless remained in a vulnerable position, since the negotiations at Lausanne established a dangerous principle of reciprocity.

The Convention on the Greco-Turkish population exchange finally had a long-term negative effect on the treatment of minorities in interstate conflicts, since it created a moral hazard problem. As an important and well-known legal precedent, it reminded governments that largescale expulsions could be legitimised ex post with an international treaty. One can very well make the case that the legal and political precedent afforded by the Greco-Turkish population exchange exposed minorities to the threat of governments conspiring with each other in order to effectuate evictions - and the international community to sanction these evictions ex post. In 1937, for example, the "Peel Commission" established by the British government proposed a population exchange between Arabs and Jews

\footnotetext{
${ }^{54}$ MeIndersma, Population Exchanges 348.
}

very much according to the Lausanne blueprint. In fact, political leaders on both sides were asked to prove the "statesmanlike vision" of the Greek and Turkish leaders of 1923: “A precedent is afforded by the exchange effected between the Greek and Turkish populations on the morrow of the Greco-Turkish War of 1922. A convention was signed by the Greek and Turkish Governments, providing that, under the supervision of the League of Nations, Greek nationals of the Orthodox religion living in Turkey should be compulsorily removed to Greece, and Turkish nationals of the Moslem religion living in Greece to Turkey. The numbers involved were high no less than some 1,300,000 Greeks and some 400,000 Turks. But so vigorously and effectively was the task accomplished that within about eighteen months from the spring of 1923 the whole exchange was completed. The courage of the Greek and Turkish statesmen concerned has been justified by the result. Before the operation the Greek and Turkish minorities had been a constant irritant. Now Greco-Turkish relations are friendlier than they have ever been before." 55 Obviously, the Peel Commission completely ignored the fact that around 1 million of the up to 1.5 million Greeks affected had been displaced long before the signing of the Lausanne Convention and that thousands of people died as a result of the expulsions. It nevertheless advocated a similar solution to the thorny Palestinian problem.

Another example of the influence of Lausanne is the German-Italian Agreement on the Transfer of the German Minority of South Tyrol of 23 June 1939, which was according to Schechtman also explicitly modelled after the Lausanne Convention. ${ }^{56}$ The allegedly positive GreekTurkish experiences were also referred to in connection with the expulsion of German minor-

\footnotetext{
${ }^{55}$ Palestine Royal Commission Report 390.

${ }^{56}$ SCHECHTMAN, Population Transfers 22.
} 
ities from Eastern Europe after the Second World War. Winston Churchill, for example, spoke before the British Parliament in December 1944 in favour of the explicit expulsion of the German populations from Eastern Europe: "Expulsion is the method which, so far as we have been able to see, will be the most satisfactory and lasting. There will be no mixture of populations to cause endless trouble. [...] A clean sweep will be made. I am not alarmed at the prospect of the disentanglement of population, nor am I alarmed by these large transferences which are more possible in modern conditions than they ever were before. The disentanglement that took place between Greece and Turkey after the last war [...] was in many ways a success, and has produced friendly relations between Greece and Turkey ever since." ${ }^{57}$ According to Yildirim the Greco-Turkish population exchange also served as an instructive precedent for the exchange of populations between India and Pakistan in 1947, which involved more than 11 million Hindus and Muslims. ${ }^{58}$

These re-interpretations as well as the Greek and Turkish national historiographies indeed contributed to the legitimisation of forced migration, as they selectively emphasised the respective advantages of the exchange for their countries. As far as the author of the present paper is concerned, time is ripe for a neutral and critical re-assessment.

\footnotetext{
${ }^{57}$ De ZAYAS, Nemesis 11.

58 YILDIRIM, Diplomacy and Displacement 13. Cf. also Schechtmann, Population Transfers in Asia 37.
}

\section{Korrespondenz:}

Prof. Dr. Athanassios PITSOULIS

University of Hildesheim

Institute of Economics and Information Science

Universitätsplatz 1

31141 Hildesheim, Germany

pitsoulis@uni-hildesheim.de

ORCID Nr. 0000-0003-0897-0557

\section{Abkürzungen:}

Siehe das allgemeine Abkürzungsverzeichnis:

[http://www.rechtsgeschichte.at/files/abk.pdf]

\section{Literatur:}

Katrin BOECKH, Von den Balkankriegen zum Ersten Weltkrieg (München 1996).

Donald BLOXHAM, The Great Game of Genocide. Imperialism, Nationalism, and the Destruction of the Ottoman Armenians (New York 2005).

Winston S. CHURCHILl, The World Crisis: The Aftermath (London 1929).

Alfred M. De Zayas, Nemesis at Potsdam: The AngloAmericans and the Expulsion of the Germans (London 1979).

Matthew James FRANK, Making Minorities History: Population Transfer in Twentieth-century Europe (Oxford 2017).

Ahmet ICDUYGU, Deniz SERT, The Changing Waves of Migration from the Balkans to Turkey: A Historical Account, in: Hans Vermeulen et al. (eds.), Migration in the Southern Balkans (IMISCOE Research Series, Cham 2015) 85-104.

Renée Hirschon (ed.), Crossing the Aegean. An Appraisal of the 1923 Compulsory Population Exchange between Greece and Turkey (New York 2003).

Keith JEFFREY, Alan SHARP, Lord Curzon and the Use of Secret Intelligence at the Lausanne Conference: 1922-1923, in: The Turkish Yearbook of International Relations 23 (1993) 79-87.

Resat KASABA, Izmir 1922: A Port City Unravels, in: Leila TARAZI FAWAZ et al. (Hgg.), Modernity and Culture. From the Mediterranean to the Indian Ocean (New York 2002) 204-229.

Alexander KORB, Homogenizing Southeastern Europe, 1912-99: Ethnic cleansing in the Balkans revisited, in: Journal of Genocide Research 18 (2016) 377-387. 
Stephen P. LADAS, The Exchange of Minorities: Bulgaria, Greece and Turkey (New York 1932).

Carlile A. MACARTNEY, National States and National Minorities (New York 1934).

Lausanne Conference on Near Eastern Affairs 19221923: Records of Proceedings and Draft Terms of Peace, Document Cmd. 1814 (London 1923).

Michael LLEWELLYN-SMiTH, Venizelos' Diplomacy 1910-23: From Balkan Alliance to Greek-Turkish Settlement, in: Paschalis M. KiTROMILIDIs (ed.), Eleftherios Venizelos. The Trials of Statesmanship, (Edinburgh 2008) 134-192.

Ders., Ionian VISION, Greece in Asia Minor, 1919-1922 (London 2005).

Christa MeINDERSMA, Population Exchanges: International Law and State Practice. Part 1, in: International Journal of Refugee Law, 9 (1997) 335-364.

Hercules MiLlas, The Exchange of Populations in Turkish Literature. The Undertone of Texts, in Renée HiRSCHON (ed.), Crossing the Aegean. An Appraisal of the 1923 Compulsory Population Exchange between Greece and Turkey (New York 2003) 221-233.

Giles MiLton, Paradise Lost. Smyrna 1922: The Destruction of a Christian City in the Islamic World, (New York 2008).

Georges MonTANDON, Frontières nationales. Détermination objective de la condition primordiale nécessaire à l'obtention d'une paix durable (Lausanne 1915).
Norman NAIMARK, Fires of Hatred. Ethnic Cleansing in Twentieth-Century Europe (Cambridge 2001).

Harold Nicholson, Curzon: The Last Phase 19191925 (London 1934).

Palestine Royal Commission Report Presented by the Secretary of state for the Colonies to Parliament by Command of his Majesty, July, 1937 (London 1937).

Alexander A. PALLIS, The Exchange of Populations in the Balkans, in: The Nineteenth Century and After 47 (1925) 1-8.

Dimitri Pentzopoulos, The Balkan Exchange of Minorities and its Impact on Greece (London 2002).

Joseph ScHECHTMAN, European Population Transfers 1939-1945 (New York 1946).

Joseph SchechtMan, Population Transfers in Asia (New York 1949).

Leonard V. SMITH, Sovereignty at the Paris Peace Conference of 1919 (Oxford 2018).

Onur YILDIRIM, Diplomacy and Displacement. Reconsidering the Turco-Greek Exchange of Populations 1922-34 (New York 2006).

Apostolos ValKalopoulos, Griechische Geschichte von 1204 bis heute (Köln 1985).

Stefan WolfF, Can Forced Population Transfers Resolve Self-determination Conflicts? A European Perspective, in: Journal of Contemporary European Studies 12 (2004) 11-29. 